\title{
SUSTAINABLE MANAGEMENT STRATEGY FOR MANGROVE FOREST OF PELITA JAYA BAY AND KOTANIA BAY, WESTERN SERAM, INDONESIA
}

\author{
Johannes M.S. Tetelepta ${ }^{1,2 *}$ Sven R. Loupatty ${ }^{1,2}$ dan M. Wawo ${ }^{1}$ \\ ${ }^{1}$ Faculty of Fisheries and Marine Science, Pattimura University \\ ${ }^{2}$ Maritime and Marine Science Center of Excelence \\ jims.tetelepta@fpik.unpatti.ac.id, svenlatupatty@gmail.com,wawomintje@gmail.com \\ Corresponding author*
}

\begin{abstract}
The coastal area of Pelita Jaya Bay and Kotania Bay is a semi enclose estuary area having three typical most productive ecosystems i.e. mangrove, seagrasses, and coral reefs with the mangrove ecosystem being the dominant one making this area a productive in fish resources. Local community neighboring this area used mangrove ecosystem for many different purposes, some of it threatening the sustainability oh the ecosystem. The objective of this study was to analyze mangrove forest sustainability and to propose sustainable mangrove forest management. Rapfish analysis was used to analyze mangrove sustainability status. A sustainable management strategy was developed using a conceptual model framework combined with the DPSIR approach. The two most sensitive attributes affecting mangrove sustainability from Leverage analysis were used as the State component from DPSIR. The result shows that overall mangrove forest sustainability was $60 \%$ and was considered fair sustain with the ecological dimension having the highest sustainable scale $(85.35 \%)$ and considered sustain, whilst institutional dimension having the lowest sustainable scale (29.10\%) and considered unsustain. The sustainable mangrove management strategy proposed consists of workshops, training, vocational education concerning EAM, as well as replanting degraded mangrove forests, monitoring, surveying, and controlling. The management strategy should be conducted based on a co-management approach.
\end{abstract}

Keywords: Mangrove forest, local community, sustainability, conceptual model framework, Kotania Bay

\section{INTRODUCTION}

Mangrove ecosystems thrive along coastlines throughout most of the tropics and subtropics, roughly between latitudes $35^{\circ} \mathrm{N}$ and $38^{\circ} \mathrm{S}$, grow over a wide range of variety of climates (Odum et al., 1982; Morrisey et al., 2007; Hutchinson et al., 2014) Around the world, mangroves are estimated to cover an area of between 180,000 - 200,000 km2 (Spalding et al., 1997 in Kairo et al., 2008). These intertidal forests play an important ecological and socioeconomical roles, e.g., by acting as a nutrient filter between land and sea (Bernini and Rezende, 2010), invaluable local and global ecologic, environmental and social importance i.e. contributing to coastline protection (Bouillon et al., 2008;), providing commercial fisheries resources (AburtoOropeza et al., 2008; Salem and Mercer, 2012; Anneboina and Kumar, 2017; Hanfah and Eddiwan, 2018), and as nursery grounds for coastal fish and crustaceans ( Kairo et al, 2008; El-Regal and Ibrahim, 2014; Kalor et al, 2019).

Despite their great value, mangroves have one of the highest rates of degradation of any global habitat - exceeding $1 \%$ of mangrove area per year (Valiela et al., 2001 in Bouillon et al., 2008; FAO, 2003). Over-exploitation, clearcutting, and pollution are amongst the major causes for the decline (Alongi, 2002; Bouillon et al, 2008), but also erroneous estimates of the health or ecological condition 
of mangroves may prove detrimental and may undermine the functionality of mangrove forests in a hidden way (Dahdouh-Guebas et al., 2005 in Kairo et al, 2008). This has led to the realistic prospect of a world without mangroves (Duke et al., 2007 in Poungparn and Komiyama, 2013). The global mangrove ecosystems are in critical condition and have been reported that the loss has amounted to 20$35 \%$ since 2000 (FAO 2007; Polidoro et al., 2010). In addition, mangrove areas are reportedly disappearing at a rate of approximately 1-2\% per year (Alongi 2015).

The Bay of Pelita Jaya and Kotania of the Western Seram District, is semi enclose waters surrounded by three most productive tropical ecosystem vis. mangrove, seagrass, and coral reef ecosystem, where the mangrove ecosystem is the most dominant. This condition makes this area productive signed by a various marine organism like shrimp, skipjack tuna, anchovy, and mackerel, some mollusks (blood clam, mangrove oyster, and terebralia), mud crab, echinoderm, and macroalgae, all of the economic importance and non-economic important (Wouthuyzen and Sapulete 1994). This area is part of an integrated regional economic development project by the government of Maluku since its accessibility and productivity for mariculture.

The extent of the mangrove area of Pelita Jaya and Kotnia tends to increase from 779.5 ha in 1972 to $1,146.4$ ha in 1997 , decreased to approximately 6.4 ha between 1993 to 1997 (Pramudji, 2001). A recent study showed a decrease of mangrove in this area from 2,363.3 ha in 2003 to 2,189.3 in 2017 (Pattihahu, 2017). The change in mangrove extent mainly due to the anthropogenic stressor. Increase in population number force local people to convert mangrove for many different purposes viz. a hedge in plant cultivation, materials for fish floating cage, burning fuel, housing material, temporary mud crab cage (field observation and personal communication).

In the coastal area of Pelita Jaya and Kotania Bay of Western Seram District, mud crab is one of the most valuable crustacean species caught by local fishermen of the villages of Pelita Jaya, Kotania, Wael, and some of
Masika Jaya. The fishing practice has been practice for more than 30 years with the target market for regional. In terms of fisheries management, almost no management practice for this fishery. There is a sign of production decreased in terms of harvested number and individual size caught (Tetelepta and Makatita, 2012; Natan et al., 2013; Van Bulouw, 2016). A sign of the unsustainable status of mud crab Scylla serrata in Kotania bay was also noticeable (Tetelepta et al., 2019).

The majority of the problems regarding coastal natural resources like mangrove and fisheries are rooted in human activities. The core element in managing the resources henceforth is human behavior. Consequently, the understanding of social and economic aspects is a crucial consideration apart from the bio-ecology of the resources. Inclusion of the socio-economic factor into the ecological factors in fisheries management is crucial to understand the complexity of the fisheries system (Barclay et al., 2017; Sobocinski et al., 2017). A decrease in fish production, including mud crab, can be resulted from several causes like high fishing intensity, unsustainable management, diseases, habitat destruction, etc. In the case of mud crab from Pelita Jaya and Kotania Bay, no specific research has been carryout to analyze this thing. It could be no proper management, high fishing capacity, and habitat degradation of the mangrove, which might cause the production decline.

In the ecosystem approach to fisheries management (EAFM), the conceptual model has become an essential tool for identifying knowledge gaps, informing research needs, and developing EAF objectives and strategies (Harvey et al. 2016; Zador et al. 2017). Conceptual models facilitate the selection of ecological and socio-economic ecosystem indicators, and they emerge as the basis for risk assessments and quantitative ecosystem models (Harvey et al. 2016, Ingram et al. 2018; Rosellon-Druker et al., 2019). The conceptual model framework developed through the driverpressure-state-impact-response (DPSIR). The causal-effect relationship between the community and the ecosystem can be identified through the DPSIR approach and scientific- 
based knowledge conceptual model can be constructed for the management (Zador et al., 2017; Diaz et al., 2018; Balzan et al., 2019). The objective of this study, therefore, was to investigate the status of the mangrove ecosystem as their important habitat and construct the strategies for sustainable management for the mangrove forest of Pelita Jaya and Kotania Bay.

\section{RESEARCH METHODOLOGY}

The study was conducted between July to December 2017 and April to August 2018 at villages of Pelita Jaya, Kotania, Wael representing Pelita Jaya and Kotania Bay of Western Seram District (Figure 1). Management practices and the use of mangrove forest by the local community was investigated through direct field observation and interviewed the local community randomly selected. A focus group discussion was also carried out to obtain the perception of the community regarding the condition of mangrove forests.

Data for sustainability study were, based on standard attributes for Rapfish Analysis
DOI: https://doi.org/10.30598/TRITONvol16issue2page53-67

(Kavanagh \& Pitcher 2004; Rapfish Group 2006; Pitcher et al., 2013) and analyzed with RAPFISH (Rapid Appraisal for Fisheries Status), a multi-dimensional scaling, done through Microsoft Excel software. To obtain the date required, a questionnaire was distributed to the local community sampled randomly and assumed to have the knowledge on mangrove in this area. The mangrove sustainability status was classified according to Pitcher $e t$ al., (2009).

For the mangrove forest sustainable management strategy, the Driver Pressure State Impact Response (DPSIR) conceptual model framework was used to construct the management strategy. This approach has been noticed as a straightforward and broad structure in linking causal effect between human and natural system, the DPSIR framework has been seen as a useful approach in analyzing problems concerning human and natural systems and seen as a useful adaptive management tool for analyzing and identifying solutions to environmental deterrents (Gari et al., 2015; Martin et al., 2018).

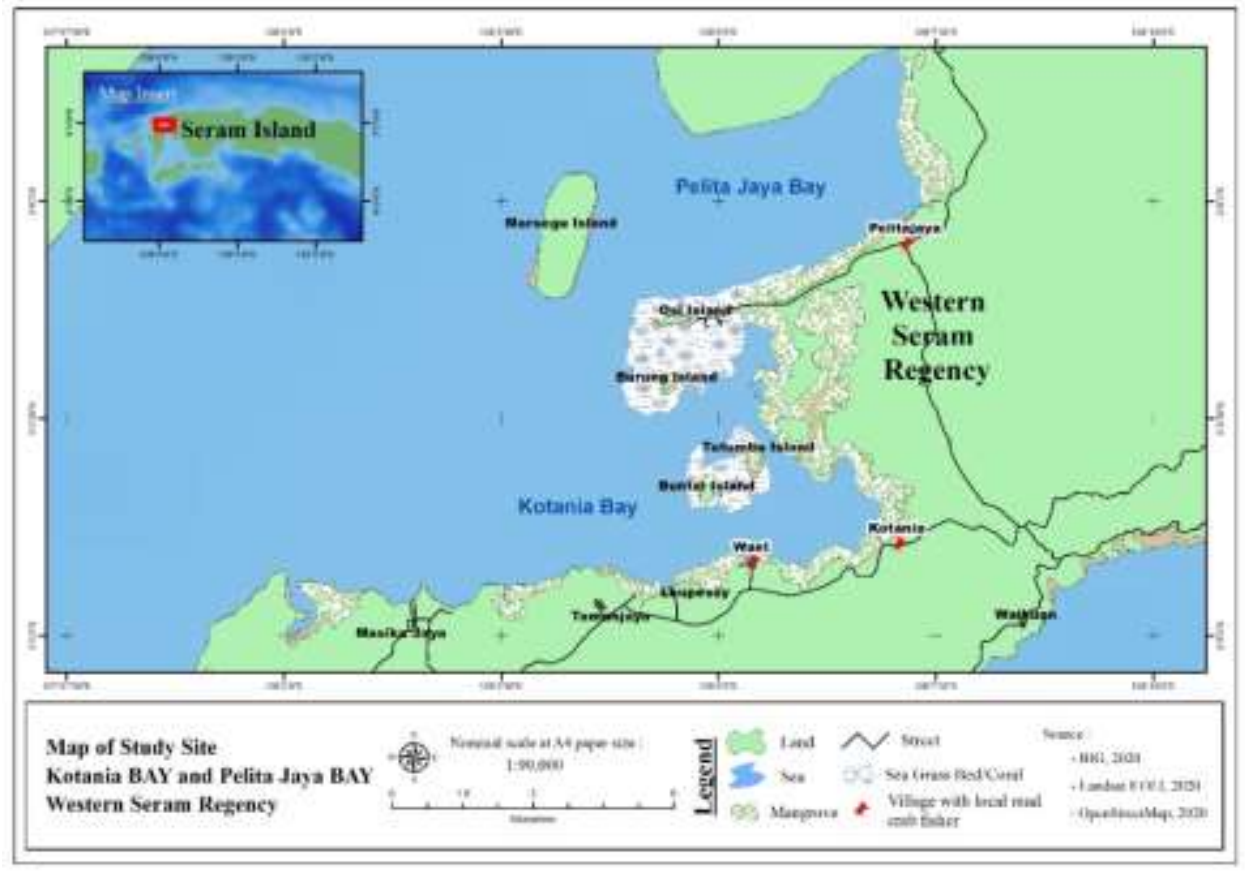

Figure 1. Map of study sites 
The leverage analysis from the Rapfish method (Pitcher and Preikshot, 2001; Kavanagh and Pitcher, 2004) was applied to determine the most sensitive variables that contribute to mangrove sustainability. A 48 variable was applied to analyze the sustainability status of the mangrove community. The conceptual model connectivity will be complicated if using all the variables, to simplify the model, thenceforth, two most sensitive variables (variable with high root mean square value) from each dimension will be used to construct the model framework. The sensitive variable will be used as a State variable of DPSIR to develop the conceptual model framework for the management strategy (Diaz et al., 2018; Balzan et al., 2019; Kell and Luckhust, 2018; Fippinger and Pearson, 2019).

Driving forces (D) are the factors that cause a change in the system in this study the mangrove, and it can be a physical, chemical, or biological factor. The local people neighboring this study site are the driver (D) towards the mangrove forests. Pressure $(\mathrm{P})$ that arises from $\mathrm{D}$ in this study is the exploitation of the mangrove, and that affects the integrity of the system (ecology, socio-economic, and institutional). State (S) is the existing condition of the component of an ecosystem that results from the $\mathrm{P}$, in this study $\mathrm{S}$ is the most sensitive attribute that affects the sustainability of the mangrove. The impact (I) component is the condition of the organism and/or the system trigger by the pressure and can be in the form of population decline, a decrease of economy revenue, social conflict, and so forth (Kell and Luckhurst, 2018; Mozumder et al., 219; Balzan et al., 2019). In the DPSIR conceptual model framework, the response $(\mathrm{R})$ is the attempt performed by the community in the form of a program or strategy to overcome the impact, and it can be at the level of $\mathrm{D}, \mathrm{P}$, or S.

A causal-effect relationship was developed based on components of DPSIR, broken down within the DPSIR framework, and then studied in detail based on the result obtained and scrutinize literature review to find every cause or factors that interacted with the element (Zador et al., 2017; Eliot et al., 2017; Mozumder et al., 2019). Every management action associated with the mangrove was examined and broken down into different parts, introducing them in the conceptual framework and connecting as responses to the driving forces, pressures, states, or impacts.

\section{RESULT AND DISCUSSION}

\section{Mangrove sustainable status}

From free sampling collection during field observation, there are six species of mangrove found in Pelita Jaya explicitly Bruguiere gymnorrhiza, Rhizophora apiculata, R. stylosa, $R$. mucronata, Cerriops tagal, and Avicenia alba. This number could be more if proper sampling is applied since the area is quite large. A study by Supriyadi and Wouthuyzen (2001) found 26 species of mangrove belong to 15 families with the dominant species of Bruguiera gymnorhiza, Rhizophora apiculate, $R$, stylosa, and Avicenia sp. For the people who live along with Pelita Jaya and Kotania Bay, the mangrove ecosystem becomes a vital ecosystem. Quite significant of the local community in these areas work as fishermen. Approximately $40 \%$ of people of Pelita Jaya Village work as fishermen, the people of Wael Village even have a large proportion being a fisherman, amount to $70 \%$, and Kotania Village with a slightly lower proportion (34\%). This shows that the mangrove ecosystem is vital due to its contribution to the productivity of this coastal area. Apart from being fishermen, some of them work as a farmer too, a typical occupation of the local coastal community in Maluku, being a farmer and fisher at the same time.

Rapfish analysis was applied to analyze the sustainability status of mangrove forests of Pelita Jaya Bay and Kotania Bay, and Monte Carlo scatters plot for stability and validity of attributes during ordination. Figure 2A. describe the ecological sustainability of the mangrove forest community. This figure shows that the sustainability of mangrove forests at Pelita Jaya, Kotania, and Wael village was $97.05 \%, 76.11 \%$, and $82.88 \%$ correspondingly from a $100 \%$ sustainable scale. According to Pitcher et al., (2009), in ecosystem approach management, mangrove from these three villages was considered sustained. The Monte Carlo Scatter 
Plot (Figure 2B) shows a congregate tendency of scatter plots signifying stability during the ordination process. The stress value was 0.1490 which is $<0.25$ showing high goodness of fit (Clarck and Warwick, 1997 in Pitcher and Preikshot, 2001), with a squared correlation $\left(\mathrm{R}^{2}\right)$ of 0.9160 .

A study on mud crab sustainability in Sorbay Bay of Southeast Maluku District shows a sustainable condition in the ecology dimension of the mud crab. The mangrove ecosystem in Sorbay Bay is still in sustainable condition (Fikri et al., 2018). Some studies on mud crab of Kotania Bay and Pelita Jaya Bay showed a decrease in the number and size of mud crab harvested (Natan et al., 2014; Van Bulow, 2016; Tetelepta et al., 2019). The use of mangrove forests in this area if not managed properly, in the long run, will affect the mud crab production. A studied in mangrove and mud crab from Kenya shows a decline in mud crab production connected to the degradation of mangrove in that area (Fondo, 2006).

The economy sustainability in Rapfish analysis assesses the attributes or variables in the economic dimension that might foster or inhibit the biological sustainability of the resources (Pitcher et al., 2013). Figure 3A displays the economy sustainability of the mangrove forest of Kotania and Pelita Jaya Bay, represented by the village of Pelita Jaya, Kotania, and Wael. This figure shows that the economic sustainability of mangrove from these three villages was $60.18 \%, 55.82 \%$, and $61.52 \%$ consecutively from a $100 \%$ sustainable scale. The sustainability value obtained revealed that the mangrove forest status for Peltta Jaya and Wael village was considered moderate sustain, while for Kotania village was considered less sustain. In the ecosystem approach management, improvement should be exercised to increase this status to sustainable conditions. The strategy for this will be discussed in detail in strategy management. Monte Carlo scatter plot shows a tight distribution of the plotted points for the reference and anchor, signaling no perturbation during rapid ordination. The stress value both for mud crab and mangrove forest was 0.1436 which $<0.25$ meaning high goodness of fit, whereas the square correlation $\left(\mathrm{R}^{2}\right) \quad$ was also high (0.9258).
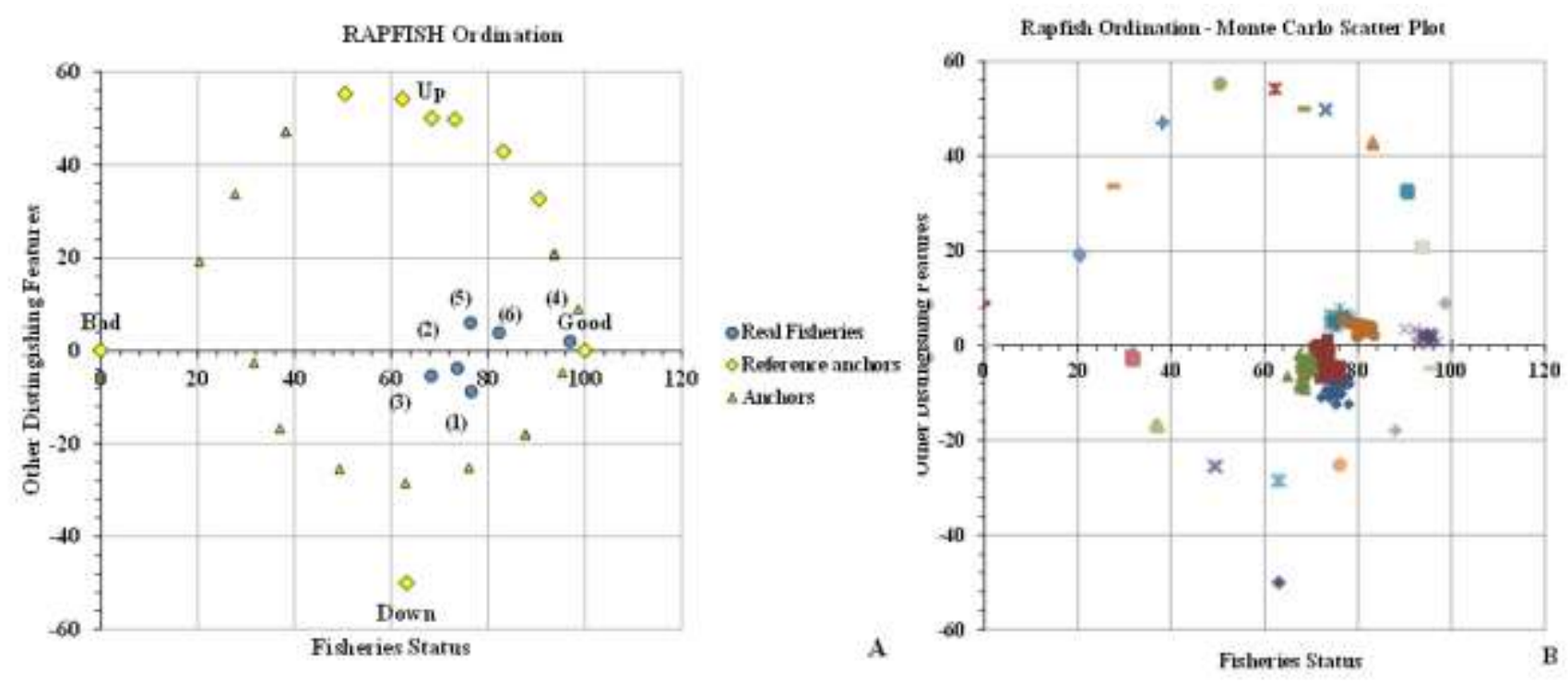

Figure 2. Rapfish ordination (A) showing mangrove forests ecology sustainability, and Monte Carlo scatter plot (B) showing the stability of the ordination 

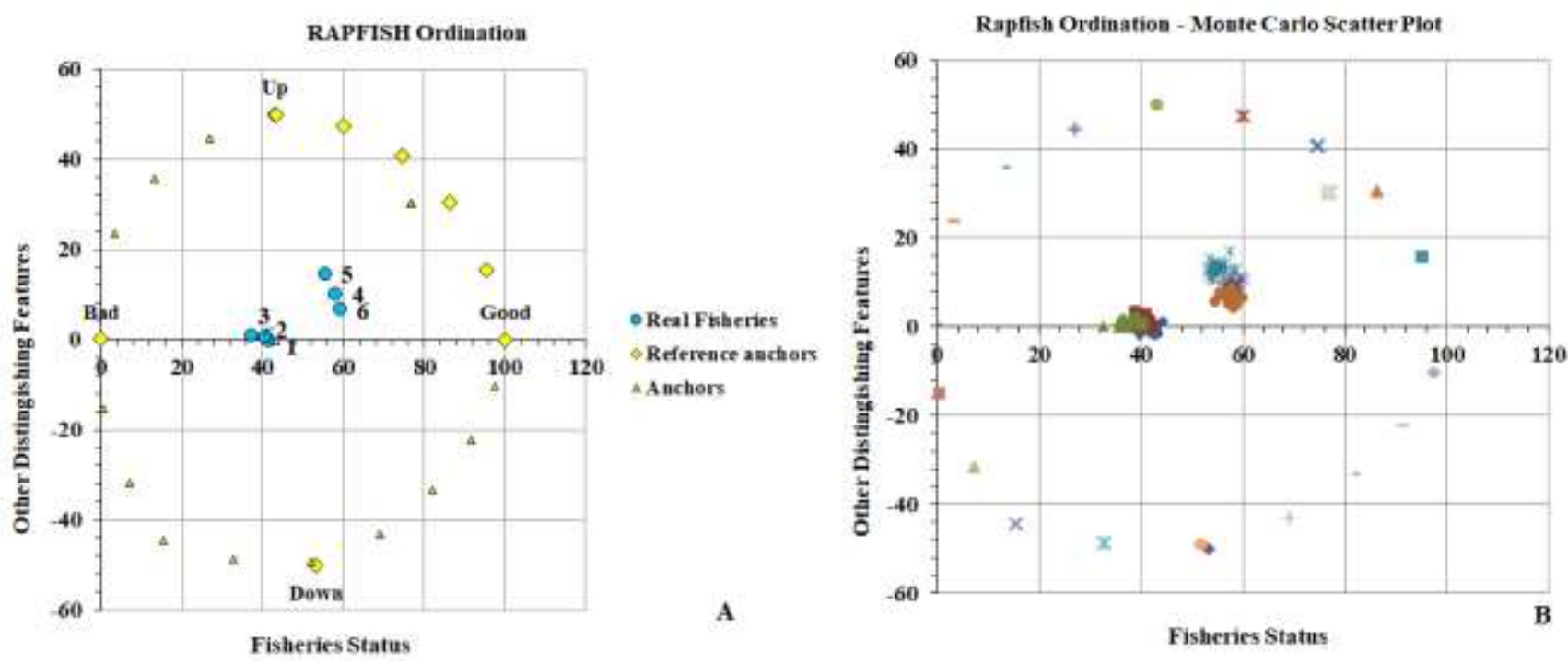

Figure 3. Rapfish ordination (A) showing mangrove forests economy sustainability, and Monte Carlo scatter plot (B) showing the stability of the ordination.

The local community lives near this area have been using the mangrove forests for many years for their daily needs. No restriction in the use of this mangrove, any person from this area can come and use the mangrove. No market system for this mangrove forest, everyone can use the mangrove by themself. The limited entry attribute if not administered properly, can threaten the sustainability of the mangrove forest in the long term. The attribute market system explains the monopoly or not a monopoly in the market. In the case of mangrove, no monopoly and no real market for the mangrove, hence this attribute foster the sustainability of the mangrove.

The Rapfish ordination and Monte Carlo scatter plot was also employed for social, technical, and institutional. Table 1 summarized the result of sustainability status, the stress value, and square correlation $\left(\mathrm{R}^{2}\right)$ for this remaining dimension. Table 1 shows the social, technical, and institutional sustainability of the mangrove forests of Pelita Jaya and Kotania Bay. The sustainability status of social and technic dimension range from $56.82 \%$ to $71.55 \%$ of $100 \%$ sustainable scale, and considered as moderate to sustain condition. The institutional dimension sustainability, on the other hand, lies from $21.71 \%$ to $34.63 \%$ from a $100 \%$ sustainable scale and was considered unsustained (Pitcher et al., 2009). The stress value for the goodness of fit test was less than 0.25 and was considered as having high goodness of fit (Clarck and Warwick, 1997 in Pitcher and Preikshot, 2001), with a square correlation lies between $0.9030-0.9562$.

Figure 4 summarizes the sustainability of mangrove forests from Pelita Jaya and Kotania Bay represented by the Village of Pelita Jaya, Kotania, and Wael. This figure shows that the sustainability status of mangrove forests varies between dimensions and between areas. According to the ecosystem approach management, the ecology sustainability of mangrove forests was considered to sustain. The most afflicting result was the institutional sustainability dimension that fell on unsustainable conditions. The sustainability of each dimension does not stand in isolated way but interconnected in the causative ways. The institutional dimension, for example, will affect the sustainability of ecological sustainability and other dimensions as well. The management strategy, therefore, should be conducted holistically and in an integrated way. 
Table 1. Summary of Rapfish ordination, stress value, and square correlation $\left(\mathrm{R}^{2}\right)$ of social, technical, and institutional dimensions of Pelitaja and Kotania Bay mangrove forest

\begin{tabular}{llcccc}
\hline \multicolumn{1}{c}{ Dimension } & \multicolumn{1}{c}{ Village } & Rapfish Ordination & Stress & $\mathrm{R}^{2}$ & Sustainable Status \\
\hline Social & Pelita Jaya & 66.59 & & & Moderte sustain \\
& Kota Nia & 56.82 & 0.1277 & 0.9563 & $\begin{array}{c}\text { Moderate sustain } \\
\text { Moderate sustain }\end{array}$ \\
& Wael & 61.57 & & & Sustain \\
\hline Technical & Pelita Jaya & 71.55 & & & Moderate sustain \\
& Kota Nia & 62.26 & 0.1707 & 0.9388 & Moderate sustain \\
& Wael & 60.00 & & & Unsustain \\
\hline Institutional & Pelita Jaya & 30.9508 & & & Unsustain \\
& Kota Nia & 21.71 & 0.1659 & 0.9562 & Unsustain \\
& Wael & 34.63 & & &
\end{tabular}

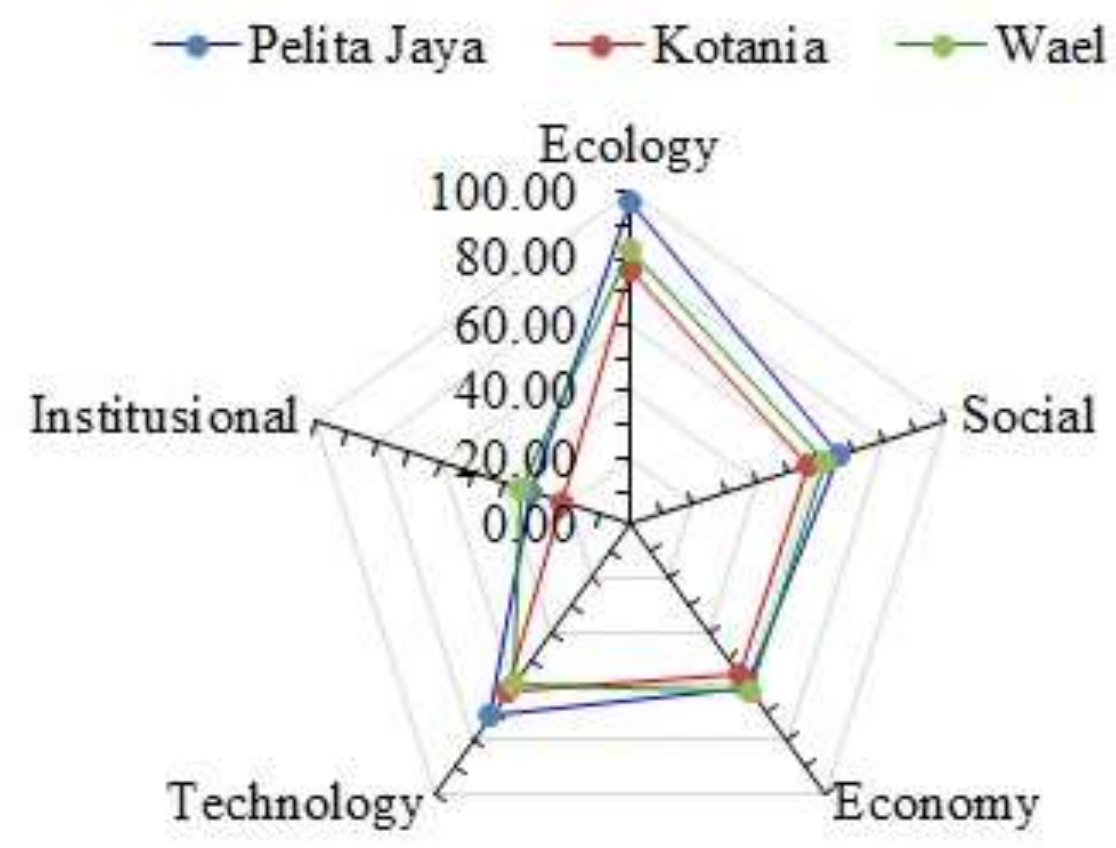

Figure 4. Kite diagram showing the sustainability status of mangrove forests of Pelita Jaya and Kotania Bay represented by the village of Pelita Jaya, Kotania, and Wael

The total number of the variable used in studying the sustainability of the mangrove forest was 48 for all the dimension. Each of the variables has its scale of sensitivity affecting sustainability. Figure 5 shows the leverage analysis of all variables from all domains analyzed. Attribute having high Root Mean Square (variance), indicating high sensitivity towards the sustainability of a particular dimension.

The four most sensitive attribute (variable) affecting the sustainability was limited entry $(\mathrm{RMS}=6.92)$ from the economic dimension, consumer attitude towards sustainability $(\mathrm{RMS}=5.94)$ from social dimension, market system (RMS $=5.65$ ) from the economy domain, and just management $(\mathrm{RMS}=5.62)$ from the social domain. All other attributes and their level of sensitivity towards the sustainability of mangrove forest is presented in Figure 5. The level of sensitivity towards mangrove sustainability range from the equity of economic benefit $(\mathrm{RMS}=0.27)$ to limited-entry $(\mathrm{RMS}=6.93)$. 


\section{Mangrove sustainable management strategy}

In an ecosystem approach to fisheries management (EAFM), three main ecosystem dimensions that become a core aspect in sustainability analysis are ecological, socioeconomy, and institutional dimensions (FAO, 2008; Pomeroy et al., 2013; Staples et al., 2014). Sustainable natural resources management performance could succeed when these three dimensions are conducted correctly. This study has revealed that only the mangrove ecological domain was in sustainable condition, the socio-economy is between less to moderate sustain, while institutional is in unsustain condition.

A total number of 48 attributes was used in studying mangroves forest sustainability status. The causal effect relationship as a basis in developing the DPSIR model conceptual framework for sustainable mangrove management will become a very complicate causal effect relationship. For a sustainable management strategy, the two most sensitive attributes from ecology, socio-economy, and institutional were applied in the State (S) component of the DPSIR conceptual model framework. Figure 6 shows the management strategy for the sustainable ecological dimension of the mangrove forest.

The two most sensitive attribute from the ecological domain was size composition and exploitation status. Size composition has a relation to young individual mangrove chop up by the community, and threaten the mangrove seedling. Some local communities also convert mangrove areas for settlement, and this also has a risk to young mangrove (Rasyid et al., 2016). Seedling is the ultimate factor for mangrove distribution. Seedling establishment and growth would extend mangrove distribution and increase land establishment as well. Environmental factors regulating mangrove growth are temperature, salinity, $\mathrm{pH}, \mathrm{DO}$, organic matter, nutrient $(\mathrm{N}, \mathrm{P}, \mathrm{K})$, sediment structure, including sand and silt composition.
(Hastuti et al., 2019). These environmental factors in this area are still in a suitable condition for mangrove forests.

In a situation where there is no entry restriction in the use of resources, the exploitation of mangrove forests will increase. With the increase in the human population, the need for the settlement area will also increase. No limited entry prohibition will increase exploitation of the mangrove that later threatens mangrove sustainability. Many studies have shown that mangroves have several functions, namely ecological, economic, physical, aesthetic, medical, etc. (El-Regal and Ibrahim, 2014; Rasyid et al., 2016; Anneboina and Kumar, 2017; Hanifah and Eddiwan, 2018). All these functions will be at risk if the exploitation status increase since no specific management plan exists.

Series of management actions that should be doing for sustainable management are increasing local community understanding of the role and importance of mangrove through workshop and training on EAM, rehabilitation on degraded mangrove ecosystem, monitoring on the use of mangrove.

The ecosystem approach management principle combines social and economic domains into one domain i.e. the socio-economy domain rather than isolation. Leverage analysis for this domain shows that the two most sensitive attributes towards mangrove sustainability were consumer attitude towards sustainability, just management from the social domain. Limited entry and market system from an economy domain was the most sensitive attribute, but the market system in this analysis considered to foster mangrove sustainability since there is no market system for the mangrove in this area. Therefore, only three attributes were employed to develop a socioeconomic management strategy for sustainable mangrove. 


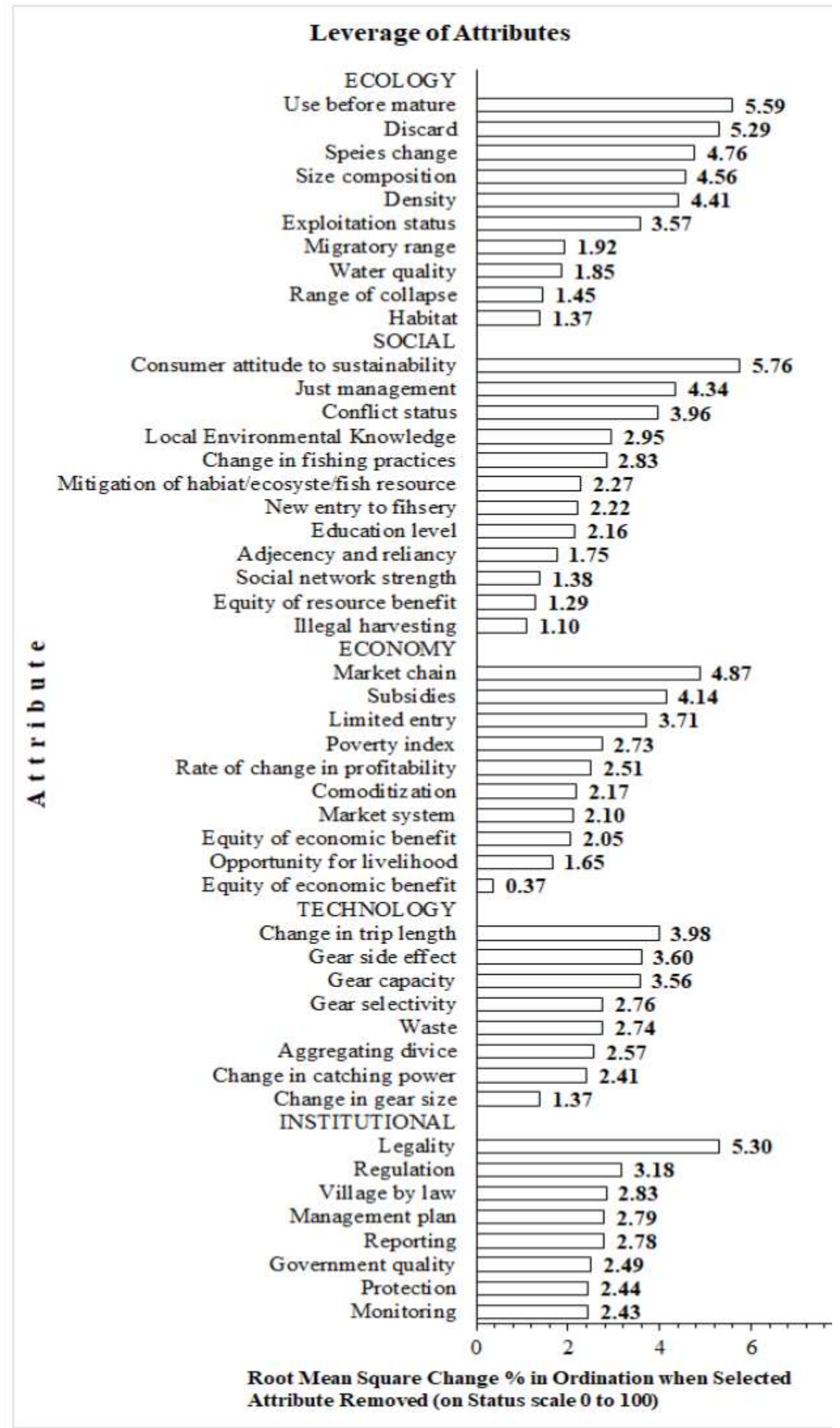

Figure 5. Leverage analysis showing sensitivity of each attribute towards sustainability of mud crab fishery and mangrove forests 


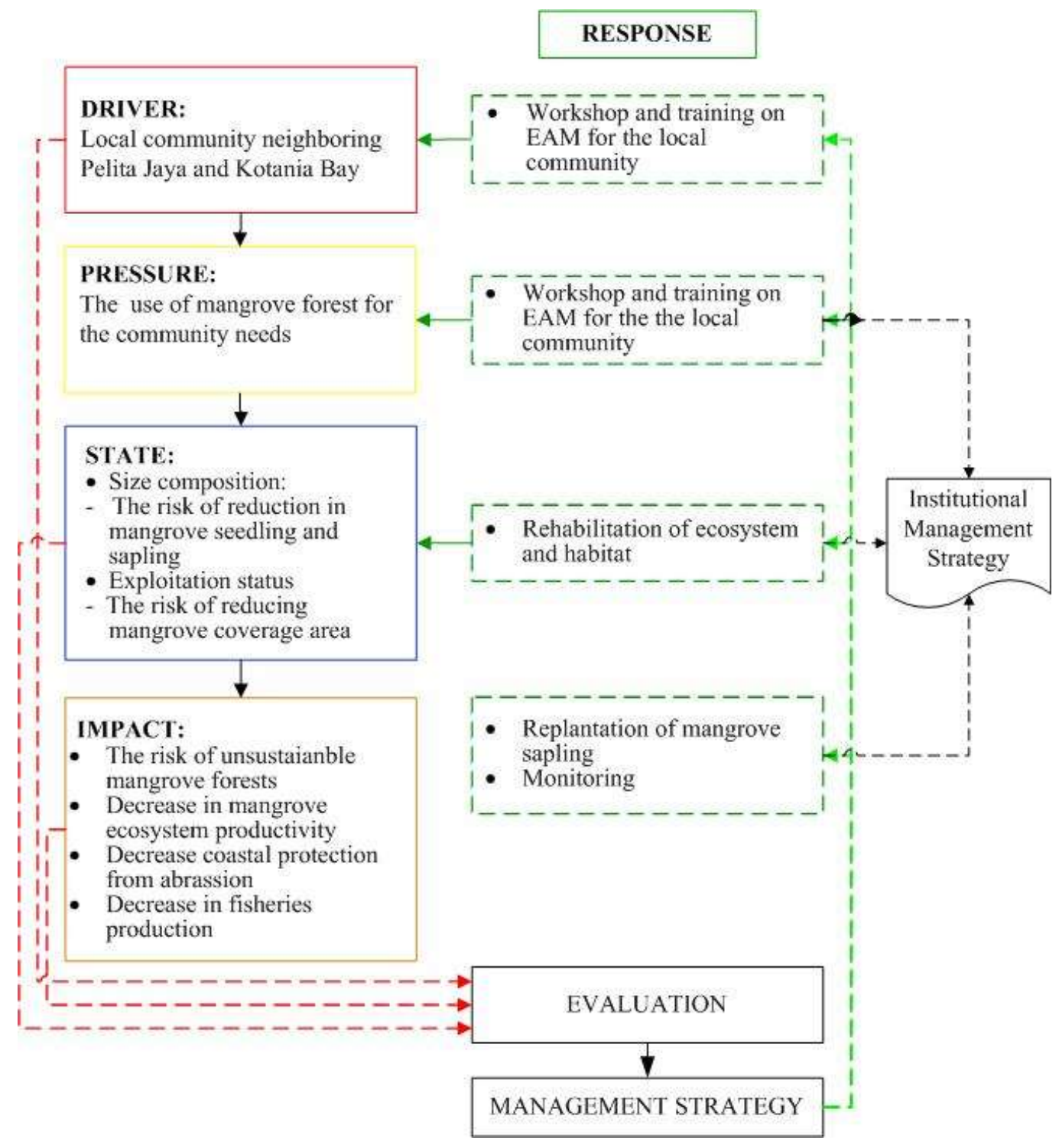

Figure 6. DPSIR conceptual model framework strategy for mangrove ecological dimension sustainability

Figure 7 shows the socio-economic conceptual model framework strategy for sustainable mangrove forest. An ecosystem approach management, the consumer attitude, assess the mindset of the community on the product delivered to them. For sustainable management, if the product is supplied to the communities with no clear sustainable management information, the communities then refused to accept it. This community mindset will enhance sustainability. In the case of the community neighboring Kotania and Pelita Jaya Bay, there is none of such an attitude. This kind of community attitude couple with no limited entry restriction to the resources will even jeopardize the mangrove. Field observation and interviews with the respondent had revealed almost no management towards mangrove. Some mangrove replantation at the village of Wael but was conducted by students conducted community service. Just management assesses the inclusion of the community in the management of the resources. In the case of mangrove management in this area, no such thing is taking place.

Community attitude towards sustainability, limited entry, and just management will lead to the unsustainable condition of the mangrove. Series of management actions that should be conducted namely workshops and training on EAFM to the community, vocational education on responsible 
management. All of these to raise the awareness' of the people on the importance and role of mangrove. The perception that mangrove contributes to the fish nursery is the strongest reason fishermen take part in the restoration. That mangrove serves as an alternative source of income for the whole community influences fisherwomen's decision to participate (Stone et al., 2008; Kaipilly et al., 2017; Setiawan et al., 2017). When the community understands the contribution of mangrove to their life, they will take part in the rehabilitation, reduce excessive use of mangrove forests.

Institutional domain in the ecosystem approach management plays crucial roles in achieving ecological and socio-economical wellbeing both for biota and for humans. The main stressor affecting the ecological wellbeing or sustainability of marine organism is human. Good institutional or governance, therefore, can control human activity in exploiting natural resources include the mangrove forest. This study shows that the two most sensitive attributes from the institutional dimension affecting mangrove sustainability were legality and reporting. Figure 8 shows a conceptual model framework management strategy for sustainable mangrove management. Monitoring, surveying, and controlling are the main element from the institutional domain which a basis for performing management plans. In the case of the mangrove forest at Pelita Jaya dan Kotania Bay, no such activity was conducted by an institution related to mangrove management or either by the local chief village.

The pressure in exploiting the mangrove forest at Pelita Jaya and Kotania Bay was the local community neighboring the mangrove area. An increase in population numbers in the last ten to fifteen years has forced the local people to use mangrove for many different purposes. There is some signpost urging the local people not to chop down the mangrove, and not to dispose of the domestic waste to mangrove area, with almost no controlling, the local keep chop up the mangrove forest, some convert it into a settlement.

The majority of the people who live nearby mangrove forests have a limited understanding of the role and function of the mangrove ecosystem. Many of them only have a junior high school background. The understanding of the importance of the mangrove ecosystem will surely help the people to enthusiastically enroll in sustainable mangrove management. Workshop, training, and vocational education of sustainable mangrove management to the local people, therefore, should be conducted to increase the community understanding and awareness towards sustainable mangrove ecosystems. Figure 8 shows some management strategies proposed in sustainable mangrove management.

Mangrove monitoring refers to the systematic collection of data and processing of these data into information about the condition, health, and coverage area of mangrove forests. It can also help to understand. Mangrove monitoring can, for example, be carried out to assess the effectiveness of planting operations and management interventions or to detect changes in forest area and land use (Schmitt and Duke, 2015). The participation of the community in the mangrove management action like replanting, rehabilitation, restoration is done through co-management principles will be more effective (Mesta et al., 2014; Jhavei et al., 2018; Hanivah and Eddiwan, 2018).

\section{CONCLUSION}

The overall mangrove forest sustainability of Pelita Jaya and Kotania Bay was $60 \%$ from $100 \%$ sustainability scale and was considered fair sustain. From the five dimensions analyzed, the ecology dimension has the highest sustainability scale $(85.35 \%)$ and is assumed to sustain. The institutional domain has the lowest sustainability scale $(29.10 \%)$ and considered unsustain Series of management strategies for sustainable mangrove forest proposed covers workshop, training, and vocational education relating to the EAFM approach as well as replanting and rehabilitation of degrading mangrove. All the management strategies recommended should be conducted based on co-management. 


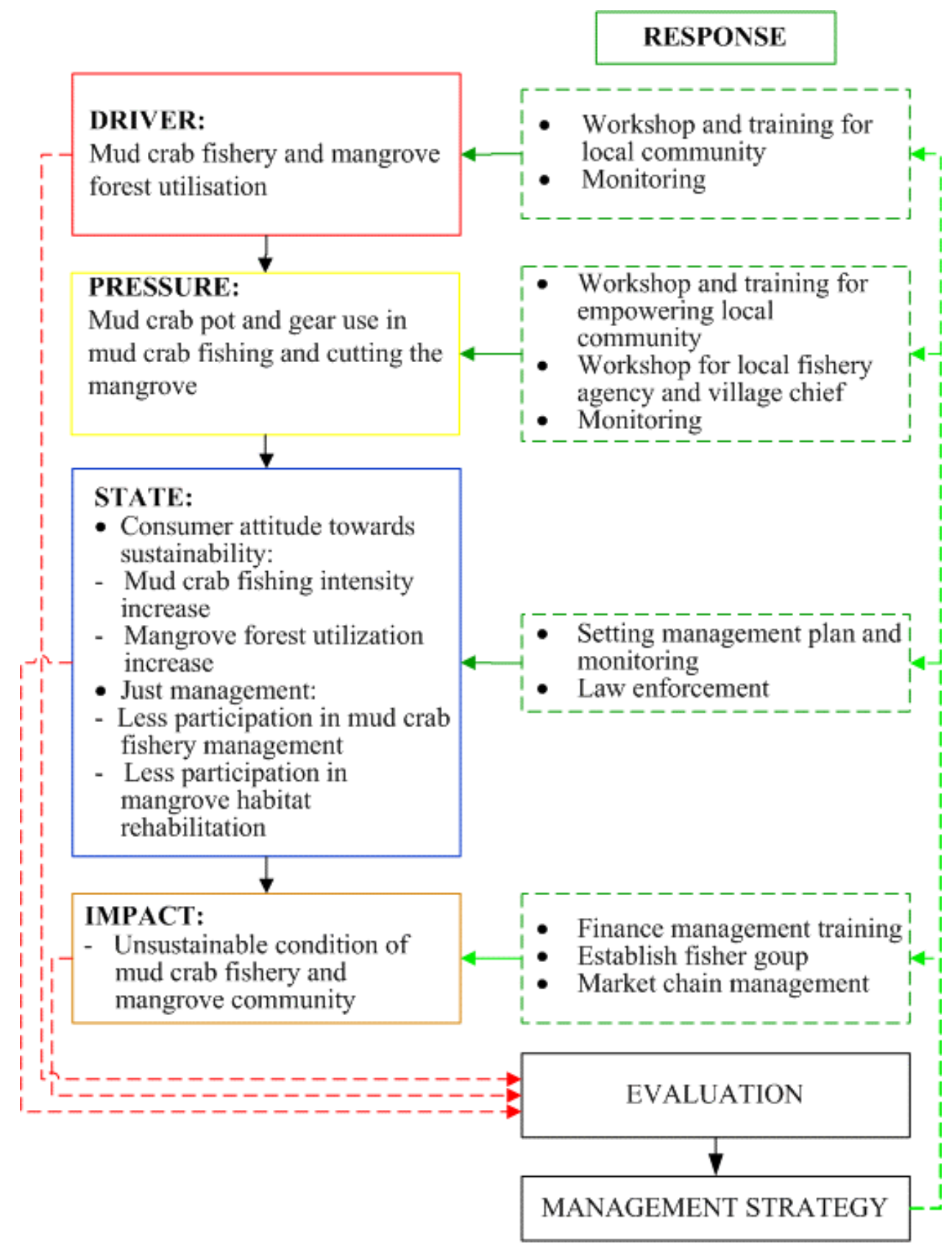

Figure 7. DPSIR conceptual model framework strategy for mangrove socio-economy dimension sustainability

\section{REFERENCE}

Aburto-Oropeza, O., E. Ezcurra., G. Danemann, V. Valdez, J. Murray, dan E. Sala. 2008. Mangroves in The Gulf of California Increase Fishery Yields. PNAS. 105:30. 10456-10459.

Barbier, E. B. 2000. Valuing The Environment as Input: Review of Applications to MangroveFishery Linkages. Ecol. Econ., 35, 47-61

Albert-Hubatsch, H., S.Y. Lee, M. Jan-Olaf, . K. Diele, I. Nordhaus and M. Wolff. 2015. Life History, Movement, an Habitat Use of Scylla serrata (Decapoda, Portunidae): Current
Knowledge and Future Challanges. Hydrobiologia. DOI $10.1007 / \mathrm{s} 10750-015-$ 2393-z. 17 p.

Alongi D., 2015. The Impact of Climate Change on Mangrove Forests. Current Climate Change Reports 1(1):30-39.

Alongi, D. M. (2002), Present State and Future of The World's Mangrove Forests. Environ. Conserv. 29. 331- 349

Anneboina, L.R. and Kumar, K.S.K. 2017. Economic Analysis of Mangrove and Marine 
Fishery Linkages in India. Ecosystem Service. 14. 114-123.

Balzan, M.V, Pinheirob A.M, Mascarenhas A, Morán-Ordóñez A, Ruiz- Frau A, Carvalho-Santos C, Vogiatzakis I.N., Arendsi J., Santana-Garcon J., Roces-Díaz J.., Brotonse L., Campagne CS, Roche PK, de Miguel S, n, Stefano Targetti o, Evangelia G. Drakou p, Vassiliki Vlamiq., Francesc Baró R.S. and Geijzendorffer, I.R. 2019. Improving Ecosystem Assessments in Mediterranean Social-Ecological Systems: A DPSIR Analysis. Ecosystem and People. 15(1): 136-155

Barclay K, Michelle V, Mazur N, Payne, A N, Mauli S, Kinh J, Fabinyi M, Smith G. 2017. The Importance of Qualitative Social Research for Effective Fisheries Management. Fisheries Research. 186. 426-438.

Bernini, E. and C.E. Rezende. 2010. Litter Fall in a Mangrove in Southeast Brazil. Pan-American Journal of Aquatic Sciences. 5:4. 508-519

Bouillon, S., A.V. Borger, E. Castaneda-Moya, K. Diele, T. Dittmar, N.C. Duke, E. Kristensen, S.Y. Lee, C. Marchand, J.J. Middelburg, V.H. Rivera-Monroy, T.J. Smith III and R.R. Twilley. 2008. Mangrove Production and Carbon Sinks: A Revision of global Budget Estimates. Global Biochemical Cycles. 22, GB2013, 12 pp.

Cisse A., F. Blanchard and O. Guyader. 2014 Sustainability of Small-Scale Fisheries: Integrated Assessment in French Guiana. Marine Policy.44:397-405

Díaz M.E., R. Figueroa, M.L.S. Alonso, and M.R.Vidal-Abarca. 2018. Exploring The Complex Relations Between Water Resources and Social Indicators: The Biobío Basin (Chile). Ecosystem Service 32: 84-92.

Diele, K., V. Koch, and U. Saint-Paul. 2005. Population Structure and Catch Composition of The Exploited Mangrove Crab Ucides cordatus in The Caete' Estuary, North Brazil: Indications of Overfishing? Aquat. Living. Resour. 18: 169- 178.

Elliott, M., D. Burdon, J.P. Atkins, A. Borja, R. Cormier, N.N. de Jonge, and R.K.Turner 2017. And DPSIR begat DAPSI (W)R(M)!" A Unifying Framework for Marine Environmental Management. Marine Pollution Bulletin. 118(20): 27-40

El-Regal, M.A.A., and N.K. Ibrahim. 2014. Role of Mangroves as a Nursery Ground for Juvenile Reef Fishes in The Southern Egyptian Red
Sea. Egyptian Journal of Aquatic Research. http://dx.doi.org/10.1016/j.ejar.2014.01.001

Food Agriculture Organization. 2007. The Worlds Mangroves 1980-2005. FAO Forestry Paper No. 153, Food and Agriculture Organization of the UN, Rome, $77 \mathrm{pp}$.

Food Agriculture Organization. 2003. State of the World's Forests. Food and Agriculture Organization of the U.N., Rome. $151 \mathrm{pp}$

Food Agricultur Oorganization. 2008. Workshop on Toolbox for the Ecosystem Approach to Fisheries. FAO Fisheries and Aquaculture Report. Nr. 884. FIFM/R884(En).Rome, 2629 February, 2008. 39 hal.

Fikri' I.A., O.P.,Darmono, J.M.S. Tetelepta, A. Damora, and W. Muzammi. Risk Potency Analysis and Sustainability Status of Mud Crab Scylla sp. of Sorbay Bay, Southeast Maluku district, Indonesia. IOP Conference Series: Earth and Environmental Science, Vol, $2169 \mathrm{p}$.

Fippinger, F.B., and S. Pearson. 2019. Report: Review of the Policy Gap Analyses of the Project Countries. Dugong and Seagrass Conservtion Project. . 42 p.

Fondo, E.N. 2007. Effect of Mangrove Deforestation on Mangrove Mud Crab Fishery. Western Indian Ocean Marine Science Association. Technical Report WIOMSA-MARG I. 20052007- $50 \mathrm{p}$.

Gari, S.R, A. Newton, and J.D. Icely. 2015. A Review of the Application and Evolution of the DPSIR Framework with an Emphasis on Coastal Social-Ecological Systems. Ocean and Coastal Management. 103: 63-77.

Hanifah, A. and K. Eddiwan. 2018. The Effect of Mangrove Forest Ecosystems on Fishing Fishery Production in the Rangsang Regency, District of Kepulauan Meranti, Indonesia. MOJ Ecology \& Environmental Sciences. 3(6): 407-412

Harvey, C.J., J.C.P. Reum, M.R. Poe, G.D. Williams, and S.J. Kim. 2016. Using Conceptual Models and Qualitative Network Models to Advance Integrative Assessments of Marine Ecosystems. Coastal Management 44(5):486-503.

Hastuti, Y.P, K. Nirmala, I. Suryani, and S L S.L. Prasetiyo. 2019. Environmental Characteristics of Mangrove Forest as a Reference for Development of Mud Crab Scylla serrata cultivation: A Case Study in Mojo Village, Ulujami, Pemalang. IOP Conf. Series: Earth and Environmental Science 278: 01203 
Hutchison, J., M. Spalding and P. zu Ermgassen. 2014. The Role of Mangroves in Fisheries Enhancement. The Nature Conservancy and Wetlands International. $54 \mathrm{p}$.

Jhaveri, N., N.T. Dzung and N.K.Dung. 2018. Mangrove Collaborative Management inVietnam and Asia. USAID. 70 p.

Kaippilly, D., E.R. Chinchu, and M.T. Geeji. 2017. Attitude and Perception of Local Inhabitants Towards Mangrove Ecosystems.Journal of Extension Education 29(4): 5984-5987

Kairo, J.G., J.K.S. Lang'at, D.B. Gebas, J. Bossire and M. Karachi. 2008. Structural Development and Productivity of Replanted Mangrove Plantation in Kenya. Forest Ecology and Management. 255: 2670-2677

Kalor, J.D., E. Indrayani, and M.N.R. Akobiarek. 2019. Fisheries Resources of Mangrove Ecosystem in Demta Gulf, Jayapura, Papua, Indonesia. ACCL Bioflux. 12(1): 219-229

Kavanagh P., T.J. Pitcher T. 2004. Implementing Microsoft Excel Software for RAPFISH: A Technique for the Rapid Appraisal of Fisheries Status. Fisheries Centre Research Reports. University of British Columbia, Canada 12(2):1-75.

Kell L.T., and B.E. Luckhurst. 2018. Extending the Indicator-Based Ecosystem Report Card to the Whole Ecosystem: A Preliminary Example Based on the Saragasso Sea. Collect Sci. Pap. ICCAT. 75(2): 258-275.

Martin, D.M., A.N. Piscopo, M.M. Chintala, T.R. Gleason and W. Berry. 2018. Developing Qualitative Ecosystem Service Relationships with the Driver-Pressure-State-ImpactResponse framework: A Case Study on Cape Cod, Massachusetts. Ecology Indicator 84: 404-415.

Mesta, P.N., B. Setturu, S.M.D. Chandran, K.S. Rajan and T.V. Ramachandra. 2014. Inventorying, Mapping and Monitoring of Mangroves Towards Sustainable Management of West Coast, India. Journal of Remote Sensing and GIS 3(3): 8 p.

Morrisey, D., C. Beard, M. Morrison, R. Craggs, and M. Lowe. 2007. The New Zealand Mangrove: Review of the Current State Oo Knowledge. Auckland Regional Council Technical Publication Number 325. 156 pp.

Mozumber, M.M.H., A. Phyl, Md.A. Wahab, S. Darkki, P. Schneider and M.M. Islam. 2019. Understanding Social-Ecological Challenges of a Small-Scale Hilsa (Tenualosa ilisha) Fishery in Bangladesh.
International Journal of Environment Research and Public Health. 16:4814.24 p.

Natan, Y. and J.M.S. Tetelepta. 2013. The Fisheries of Mud Crab Scylla serrata in the Coastal Area of Pelita Jaya Bay: A Case Study of Local Fishermen of Pelita Jaya Village. $9^{\text {th }}$ International Small Island Conference. 11-13 July, Tual, Langgur, Maluku Tenggara

Natan, Y., A.S. Khouw, J.M.S. Tetelepta and St. Siaila, St. The Fishery of Mud Crab Scylla serrata and The Empowering of the Local Mud Crab Fisher Economy, Piru Sub-District, Western Seram: Potency, Utilization, and Development. Second Year Report MP3EI Research Grant. Pattimura University. Tahun Riset Terapan. Tahun I:111. Universitas Pattimura. 45 p. [In Indonesia]

Odum, W.E., C.C. McIvor, and T.J. Smith, III. 1982. The Ecology of the Mangroves of South Florida: A Cornunity Profile. U.S. Fish and Wild Life Service, Office of Biological Services, Washington, D.C. FW/OBS-81/24. $144 \mathrm{pp}$.

Pattimahu, D.V. 2017. The Analysis of Change in Mangrove Coverage Area at Western Seram Disrict, Maluku. Jurnal Hutan Pulau Pulau Kecil 1(1): 22-27

Pitcher T.J., D. Kalikoski, K. Short, D. Varkey, and G. Pramod. 2009. An Evaluation of Progress in Implementing Ecosystem-based Management of Fisheries in 33 Countries. Marine Policy. 33:2. 223 - 232

Pitcher, T.J. and D. Preikshot. 2001. RAPFISH; a Rapid Appraisal Technique to Evaluate Sustainability Status of Fisheries. Fisheries Research 49: 255-270.

Polidoro B.A., K.E. Carpenter, L. Collins, N.C. Duke, A.M. Ellison, J.C. Ellison, E.J. Farnsworth, E.S. Fernando, K. Kathiresan, N.E. Koedam, S.R. Livingstone, T. Miyagi, G.E. Moore, V.N. Nam, J.E. Ong, J.H. Primavera, S.G. Salmo, J.C. Sanciangco, S. Sukardjo, Y. Wang and J.W.H. Yong. 2010. The Loss of Species: Mangrove Extinction Risk and Geographic Areas of Global Concern. PLoS ONE 5(4): e10095.

Pomeroy, R., R. Brainard, M. Moews, A. Heenan, J. Shackeroff, and N. Armada. 2013. Coral Triangle Regional Ecosystem Approach to Fisheries Management (EAFM) Guidelines. Publication. Honolulu, Hawaii: The USAID Coral Triangle Support Partnership.

Poungparn, S. and A. Komiyama. 2013. Net Ecosystem Productivity Studies in Mangrove 
Forests. Reviews in Agricultural Science, 1: 61-64

Pramudji. 2001. Dynamic of Mangrove Forest Area in The Coastal Area of Kotania Bay, Western Seram. Oseana. XXVI(3): 9-16 [In Indonesia]

RAPFISH Group. 2006 Standard Attributes for Rapfish Analysis: Evaluation Fields for Ecological, Technological, Economic, Social and Ethical Status. Fisheries Centre, UBC, Vancouver. 5 pp.

Rasyid, A., M.A.S. Akbar, N. Nurdin, I. Jaya, and Ibrahim. 2016. Impact of Human Interventions on Mangrove Ecosystem in Spatial Perspective. IOP Conf. Ser.: Earth Environ. Sci. 47012041

Rosellon-Druker, R., M. Szymkowiak, C.J. Cunningham, S. Kasperski, G.H. Kruse, H. Jamal, J.H. Moss and E.M. Yasumiishi. 2019. Development of Social-Ecological Conceptual Models as The Basis for an Integrated Ecosystem Assessment Framework in Southeast Alaska. Ecology and Society 24(3):30 p.

Saenger, P., D. Gartside, and S. Funge-Smith. 2013. A Review of Mangrove and Seagrass Ecosystem and Their Linkage to Fisheries and Fisheries Management. RAP Publication. FAO. 9:74pp.

Salem, M.E., and D.W. Mercer. 2012. The Economic Value of Mangrove: A MetaAnalysis. Sustainability. 4: 359-383;

Setiawan, H, R. Purwant and R. Garsetiasih. 2017. Perception and Attitude of The Community Towards Mangrove Conservation at Tanakeke Island, South Sulawesi. Journal of Social Research and Forestry Economy 14(1): 57-70

Sobocinski, K L, C.M. Greene and M.W. Schmidt. 2017. Using a Qualitative Model to Explore The Impacts of Ecosystem and Anthropogenic Drivers Upon Declining Marine Survival in Pacific Salmon. Environmental Conservation 45(3): $14 \mathrm{p}$.

Staples, D., R. Brainard, S. Capezzuoli, S. FungeSmith, C. Grose, A. Heenan, Hermes, R., Maurin, P., Moews, M. C. O'Brien and R.
Pomeroy. 2014. Essential EAFM. Ecosystem Approach to Fisheries Management Training Course Volume 1 - For Trainees. RAP Publication 2014/13

Stonea, K., M. Bhata, R. Bhatta and A. Mathews. 2008. Factors Influencing Community Participation in Mangroves Restoration: A Contingent Valuation Analysis. Ocean and Costal Management 51(6). 476-484

Tetelepta, J.M.S. and M. Makatita. 2012. An Approach to The Management of Mud Crab Scylla serrata Through Reproductive Status of Mud Crab, Socio-Economy and Institutional Aspects of The Fishermen of Pelita Jaya, Western Seram, Maluku Province. TRITON: Jurnal Manajemen Sumberdaya Perikanan. 8(1): 1-11

Tetelepta, J.M.S., Y. Natan, J.A. Pattikawa, O.T.S. Ongkers and and B.J. Pattiasina. 2019. Fishery of Mud Crab Scylla serrata of Kotania Bay, Western Seram District: Potency, Stock Status and Sustainable Management. IOP Conference Series: Earth and Environmental Science, Volume 339

Van Bulouw, D. 2016. The Fishery of Mud Crab Scylla spp. at Kotania Bay, Western Seram District. Thesis. Marine Science Postgraduate Program. Pattimura University. 98 p. [In Indonesia].

Walton, M. E. M., L. Le Vay, L. M. Truong, and V.N. Ut. 2006. Significance of MangroveMudflat Boundaries as Nursery Grounds for the Mud Crab, Scylla paramamosain. Marine Biology 149: 1199-1207

Wouthuyzen, S. and D. Sapulete. 1994. The Condition of Western Seram Coastal Water Past and Present; A review. Ambon. Perairan Maluku dan Sekitarnya. Vol. 7 [In Indonesia]

Zador G.Z., S.K. Gaichas, S. Kasperski, C.L. Ward, R.E. Blake, N.C. Ban, A.H. Cornell, and J.Z. Koehn. 2017. Linking Ecosystem Processes to Communities of Practice Through Commercially fished Species in the Gulf of Alaska. ICES Journal of Marine Science. 74(7): 2024-2033. 